\title{
Applications of endophytic-fungal-isolates from velamen root of wild orchids in floriculture
}

\section{Azhanthanilkunnathil S. Deepthi ${ }^{1}$ and Joseph G. Ray ${ }^{2}$}

\author{
${ }^{1}$ Laboratory of Plant Science and Ecology. School of Biosciences. Mahatma Gandhi \\ University. Kottayam. Kerala, India. \\ ${ }^{2}$ School of Biosciences. Mahatma Gandhi University. Kottayam. Kerala, India. \\ Email:jgray@mgu.ac.in.
}

\begin{abstract}
The velamen roots are quite extensively growing and profusely branched organ of adaptation in epiphytic orchids. The endophytic-fungi in such roots are believed to have growthpromoting influence, especially on the roots itself. However, an application of the same in the cultivation of the ornamental orchids is not yet sufficiently tried. The present report deals with the growth promoting effects of endophytic fungi of the velamen roots of a wild epiphytic orchid Acampe praemorsa on an ornamental orchid, Dendrobium sp. The five endophytic fungal species, Trichoderma asperellum, Trichoderma harzianum, Trichoderma atroviride, Endomelanconiopsis endophytica and Diaporthe eucalyptorum isolated from the velamen roots of the epiphytic orchid, $A$. praemorsa were found to be potent producers of the hormone indole-3-acetic-acid (IAA). The endophytic fungi were identified by morphological and molecular methods. The nucleotide sequences of the identified strains were deposited in the GenBank. The growth-promoting influence of them was tested on an ornamental orchid Dendrobium sp. Experimental assessment of nutrient uptake, chlorophyll content, and biomass of the leaves of the treated plants after 45 days of inoculation confirmed the growth promoting effects. The amount of nitrogen, phosphorus and potassium in the treated plants showed a significant increase from the control. The fungus $E$. endophytica showed a significant increase in the chlorophyll content in the leaves of treated plants; T. asperellum and D. eucalyptorum showed a significant increase in the fresh-weight of treated plants, whereas T. asperellum and E. endophytica significantly increased the dry weight of leaves in treated plants. Overall, the experiment proved that the endophytic fungal isolates from the wild orchid A. praemorsa synthesize bioactive compounds including IAA that can promote growth in ornamental orchids such as Dendrobium sp. Thus the endophytic fungal isolates from wild orchids are proved significant in orchid floriculture.
\end{abstract}

Keywords: Endophytic-fungi; Epiphyte; Growth promotion; IAA; Orchid; Velamen roots.
Received

September 23, 2019

Accepted

December 27, 2019

Released

December 31, 2019

Full Text Article

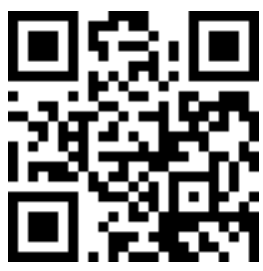

ORCID

D 0000-0002-0622-9581 Azhanthanilkunnathil S. Deepthi

(ㄱ) 0000-0001-5045-050X Joseph G. Ray 


\section{Introduction}

The symbiotic fungal endophytes are beneficial to its host (Wang et al., 2015).The fungal endophytes are potent producers of phytohormones and other bioactive compounds (Khan et al., 2015) in many plants. In general, endophyticfungi are believed to be significant in the natural existence of many species of plants (Kedar et al., 2014). Therefore, exploration of such fungi, quite common in wild species can have potential application in agriculture, horticulture, biotechnology and the natural products industry (Guo et al., 2008; Nisa et al., 2015). Besides, the secondary metabolites extracted from many endophytic fungi (Xing et al., 2011), are significant as pharmaceuticals, biocontrol agents (Chen et al., 2010) and growth-promoting compounds in cultivated plants. In general, wild Orchids are well-known for rich endophytic associates in different parts of its plant body.

Orchidaceae, one of the largest families of flowering plants (Correll, 1950), include many species of epiphytes and lithophytes. In general, at the young stage, epiphytic orchids survive with the support of fungal symbionts and become autotrophic only at adulthood (Kohout et al., 2013). The plant Dendrobium, an epiphytic orchid is the second largest genus of the Orchid family with more than 1000 species (Shah et al., 2019). It is one of the most popular ornamental orchid valuable as cut flowers in South Asia (Hágsater and Dumont, 1996). Endophytic association is well known in Dendrobium spp. (Yuan et al., 2009; Mohamed and Joseph, 2016). However, applications of endophytic fungi from wild Orchids, especially that from the velamen roots are not yet tried in this plant.

The velamen roots are morphologically and biologically unique hanging roots in epiphytic Orchids. Such roots, in general, are growing excessively long and remain profusely branched in
Orchids, but the reason behind the same remains quite strange. The velamenroots are often found inhabited by several microorganisms (Tsavkelova et al., 2003). Since epiphytic orchids survive under frequent water-stress and low availability of nutrients (Zotz and Hietz 2001) with velamen roots, the fungalendophytes in the same are believed to play an important role of procuring and retaining nutrients (Zotz and Winkler 2013) for such plants. Infact, the symbiotic microbes in velamen roots help in the synthesis of plant hormones (Tsavkelova et al., 2008; Waqas et al., 2012) such as indole-3-acetic-acid (IAA), gibberellins or cytokinins (Hamayun et al., 2009; Khan et al., 2012; Yang et al., 2014) which might be one of the reasons for the extensive growth and profusebranching of such roots. The microbial associates are also found enhancing the uptake of nutrients by velamen roots (Hamayun et al.,2010; Senthilmurugan and Sekar, 2015). Fungal endophytes are responsible for increase in the rate of photosynthesis in host plants (Hermosa et al., 2012) by diverse means.

In general, the wild Orchid Acampe praemorsa (Roxb) Blalt \& Mc Cann is quite common in diverse environments in tropical Kerala including trunks of trees on road sides. It shows luxuriant growth and remains highly resistant to diseases with plenty of velamen roots. In a recent study, a number of fungal endophytes are found associated with the velamen roots of this Orchid (Deepthi and Ray, 2018). Therefore, it was assumed that the endophytic-fungal species in its velamen roots play a significant role in the vigorous growth of this wild Orchid species. In this context, the growthpromoting effects of velamen rootassociated endophytic fungal isolates of this plant were tested on a hybrid cultivar of epiphytic ornamental Orchid, Dendrobium sp., (Dendrobium; Thongchai Gold x Lasianthera).

The major goal was to explore the potential use of velamen root-associated 
endophytic fungal isolates of $A$. praemorsa as growth promoters in the organic cultivation of ornamental Orchids. The appearance of growthpromoting hormone in the fungal culture medium such as IAA was used as the criterion for selecting fungal species from the velamen roots of the wild Orchid for testing its growth promoting influence on the cultivated species. The five endophytic- fungal isolates from the velamen roots of this Orchid found producing IAA in the culture medium were Trichoderma asperellum, Trichoderma harzianum, Trichoderma atroviride, Diaporthe eucalyptorum and Endomelanconiopsis endophytica. The change in nutrient-uptake and growth parameters of the fungal treated Dendrobium sp. were assessed after 45 days of inoculation to account the degree of growth-promoting influence of the endophytic fungal isolates from wild Orchids on the cultivated Orchid species.

\section{Materials and methods}

\section{Isolation of fungal endophytes}

Healthy hanging medium sized velamen roots of $A$. praemorsa were collected from open fields of Kerala state, India. The velamen roots were carefully detached from the plants, stored in polyethene bags, transferred to the laboratory and processed within 24 hours of collection. The fungal endophytes were isolated from the velamen roots as per standard procedures. Surface sterilization and isolation of endophytic fungi were done as per Bayman et al. (1997) with some modifications. In brief, roots were washed thoroughly with tween 20 followed by running tap water to remove dust and debris and surface sterilized in a sequence of $70 \%$ ethanol for 1 minute, $2.5 \% \mathrm{NaClO}_{2}$ for 1 minute and rinsed three times in sterile distilled water. The roots were cut into $5 \mathrm{~mm}$ segments using a sterile blade. The segments were placed in Petri dishes containing approximately $15-20 \mathrm{ml}$ of potato dextrose agar medium (PDA) of $\mathrm{pH} 5.8$, malt extract agar medium (MEA) of $\mathrm{pH}$ 5.8 and sabouraud dextrose agar medium (SDA) of $\mathrm{pH}$ 5.6. $100 \mu \mathrm{g} \mathrm{ml}^{-1}$ streptomycin was added to each medium to prevent bacterial growth. Before plating, imprints of the segments were made on the medium to check the efficacy of surface sterilization (Schulz et al.,1993). Samples were incubated at $28^{\circ} \mathrm{C}$ with $12 \mathrm{~h}$ alternate light and dark period. The fungal growth from the incubated segments was monitored at every two days for two weeks. Hyphae emerging from the segments were transferred to fresh PDA without antibiotic for purification and identification. All the details of morphological and molecular taxonomic characterization of the fungi are already reported (Deepthi and Ray, 2018).

\section{Initial screening of endophytic fungi for IAA production \\ For the initial screening of} isolated strains for IAA production, pure cultures of fungal isolates were allowed to grow in $50 \mathrm{ml}$ potato dextrose broth (PDB) supplemented with $0.2 \%$ tryptophan and incubated on a rotary shaker for 7 days. After seven days it was centrifuged and the supernatant was collected. To $1 \mathrm{ml}$ of the culture filtrate (CF), added $2 \mathrm{ml}$ Salkowski's reagent $(0.5$ $\mathrm{M} \mathrm{FeCl2}$ and $35 \%$ perchloric acid) and incubated in the dark for 30 minutes. After incubation, the absorbance (OD) of the reaction mixture was taken at 530 $\mathrm{nm}$ against blank. The concentrations of IAA present in each sample were calculated using the standard curve plotted with the OD values of known concentrations of IAA (10- $10000 \mu \mathrm{g} / \mathrm{ml})$.

\section{Confirmation of IAA production by HPLC analysis \\ To confirm the presence of IAA in the culture supernatants a modification of high-performance liquid} chromatography (HPLC) method was used (Tsavkelova et al., 2007). Selected fungal strains were allowed to grow on 
PDB. Five discs of seven days old fungal colony of about $1 \mathrm{~mm}$ diameter were put in the PDB with $0.2 \%$ tryptophan and incubated at $28^{\circ} \mathrm{C}$ in a shaker with 150 rpm for 7 days. Cell-free supernatants were harvested by centrifugation at 7000 rpm for 10 minutes and $\mathrm{pH}$ was adjusted to 2.8 with $1 \mathrm{~N} \mathrm{HCl}$ and extracted three times with double volume ethyl acetate by vigorous shaking for 20 minutes. After separation of two layers, the ethyl acetate fraction was evaporated under vacuum. The solid residue was dissolved in $1 \mathrm{ml} \mathrm{HPLC} \mathrm{grade} \mathrm{methanol,} \mathrm{centrifuged}$ at $8000 \mathrm{rpm}$ for 10 minutes and filtered through $0.22 \mu$ membrane filters. HPLC analysis was performed by injection of $20 \mu \mathrm{l}$ of aliquots onto a Luna C 18 $(250 \times 2.5 \mathrm{~mm})$ column connected to HPLC pump (LC- 20 AD). Absorbance was monitored at $280 \mathrm{~nm}$. The mobile phase was acetonitrile: water: acetic acid (60: 40:1, v/v) at a flow rate of 1 $\mathrm{ml} /$ minute. Retention time for the analyte peaks was compared with authentic internal standards added to the PDB and extracted by the same procedures.

\section{Growth promotion studies of fungal endophytes on Dendrobium sp. The experimental plant} material. The micro propagated plantlets of a hybrid cultivar of epiphytic ornamental orchid Dendrobium sp. (Thongchai Gold $\times$ Lasianthera) bought from the Angel gardens at Paipad, Kerala state, India is used for studying the growth-promoting potential of endophytic fungi. Micro propagated plantlets which are kept in aseptic conditions were used because the potted and field collected plants are usually colonized by endophytic fungi (PorrasAlfaro and Bayman 2007). Thirty days old plantlets of about $8-10 \mathrm{~cm}$ length with 10-15 roots and 3 or 4 leaves were used for inoculating with fungal cultures.

Preparation of the inoculum. The five endophytic fungi, T. asperellum
(APVR 07), T. harzianum (APVR 22), E. endophytica (APVR 23), D. eucalyptorum (APVR 25) and T. atroviride (APVR 33) isolated from the velamen roots of $A$ .praemorsa were selected to test their ability of stimulating the growth in Dendrobium sp.

Sterilized coconut coir pith and coconut chip mix $(1: 1 \mathrm{w} / \mathrm{w})$ were used as the growth medium in pots. It was previously moistened with distilled water. In about $400 \mathrm{~g}$ of the mixture, 100 $\mathrm{ml}$ of PDA with $0.8 \%$, agar was added, packed in polyethene bags and tied well. Each bag was then subjected to double sterilization of 24 hours interval at $121^{\circ} \mathrm{C}$ for 20 minutes. Each bag was aseptically inoculated with 10 square plugs of the $1 \mathrm{~cm}$ size of actively growing five days old fungus cultures. The controls were mock inoculated with 10 plugs of $1 \mathrm{~cm}$ size plane PDA. The polyethene bags were kept for two weeks at $28^{\circ} \mathrm{C}$ in 12 hours of light and dark period for optimal fungal growth. They were shaken two times a day for two weeks. After two weeks contents of each polyethene bag was emptied into a pot and one Dendrobium sp. plantlet was planted in each pot.

The experimental design and
plant growth conditions. The
experiment was carried out for a period of 45 days in April-May 2017. Complete randomized block design (CRBD) with one variety, control, and five different treatments were used. Control and each treatment were replicated six times. The plants were kept on the rooftop, School of Biosciences, Mahatma Gandhi University, Kottayam District, Kerala State. The plants were kept under the green net (mesh size to reduce 50\% photo intensity) to avoid direct sunlight and rainfall. The average irradiance in the growing place was $50 \%$ of 5.06 to $5.41 \mathrm{kWh}^{-1} \cdot \mathrm{m}^{-2}$. day $^{-1}$. An average of six sunshine hours was available per day with an average air temperature of $27^{\circ} \mathrm{C}$ $30{ }^{\circ} \mathrm{C}$ and average $77 \%-78 \%$ relative humidity. 
Analysis of growth parameters

After 45 days of co-cultivation, the plantlets of each treatment $(\mathrm{N}=36)$ were harvested separately. The symbiotic effect of fungi on vegetative growth of the host plant was assessed by fresh weight (FW), average dry biomass (DW) and chlorophyll content of the leaves. The upper four leaves from each plant were selected for determining the FW. The DW of the leaf was determined after drying $5 \mathrm{~g}$ fresh leaf tissue at $60{ }^{\circ} \mathrm{C}$ till a constant weight is attained; chlorophyll content of the fresh leaves was estimated as per Arnon (1949). The nutrient uptake of the plants was determined by estimating the nitrogen, phosphorus, and potassium (NPK) content of leaves. Sample preparation for NPK was done as per AOAC (1978). The estimation of nitrogen was carried out by the micro-Kjeldahl method (AOAC 1978); tissue $\mathrm{P}$ and $\mathrm{K}$ were measured after triple acid digestion. The estimation of tissue $\mathrm{P}$ was carried out by Valado- molybdate yellow colour method (Jackson, 1973) and $\mathrm{K}$ by flame photometry (Labronics LT-671).

\section{Statistical analyses of data}

The data were analyzed statistically for standard deviation using MS-EXCEL2010. All the data were analyzed following standard procedures for one way analysis of variance (ANOVA). The differences between means were evaluated for significant level following Duncan's Multiple Range Test (DMRT) using SPSS 16.0 software. Graphs were prepared using graph pad prism software (version 5.0, San Diego, California USA).

\section{Results}

\section{Production of IAA by the endophytic fungi}

The concentration of IAA estimated by Salkowski's method
(Table1) from the CFs of the fungal isolates was variable APVR 07 (544.97 $\mu \mathrm{g} / \mathrm{ml})$, APVR $22(167.86 \mu \mathrm{g} / \mathrm{ml})$, APVR $23(191.23 \mu \mathrm{g} / \mathrm{ml})$, APVR 25 (276.27 $\mu \mathrm{g} / \mathrm{ml})$ and APVR $33(289.87 \mu \mathrm{g} / \mathrm{ml})$. The HPLC analysis of the CFs also confirmed their capability for in vitro production of IAA. The standard IAA and culture extracts had peaks at the retention time of 12 minutes (Figure 1).

The exact identity of the five isolates was confirmed as Trichoderma asperellum (APVR 07), Trichoderma harzianum (APVR 22), Endomelanconiopsis endophytica (APVR 23), Diaporthe eucalyptorum (APVR 25) and Trichoderma atroviride (APVR 33) by nrITS DNA barcoding. The genetic sequences of the fungal taxa were submitted in the Gen Bank and already received accession numbers (Table 1 ).

The growth parameters such as FW, DW and chlorophyll content of the leaves and the uptake of NPK in the fungal treated plantlets were compared with an uninoculated control after 45 days of inoculation (DAI). All the treatments were found significantly $(P<$ 0.001 ) enhancing nitrogen accumulation from the control in Dendrobium sp. The highest accumulation of nitrogen $(2.19 \%)$ was observed in the plantlets treated with $T$. harzianum and the lowest accumulation of nitrogen was noted in the plantlets treated with fungal isolate T. atroviride $(1.64 \%)$.

Similarly, all the endophyticfungal inoculants showed a statistically significant increase in the accumulation of potassium content from the control $(P$ $<0.001$ ) in the leaves of Dendrobium sp. The treatment with fungal inoculant $D$. eucalyptorum showed the highest potassium content $(1.26 \%)$ whereas the treatment with E. endophytica $(0.67 \%)$ showed the lowest potassium content in the leaves of Dendrobium sp. 

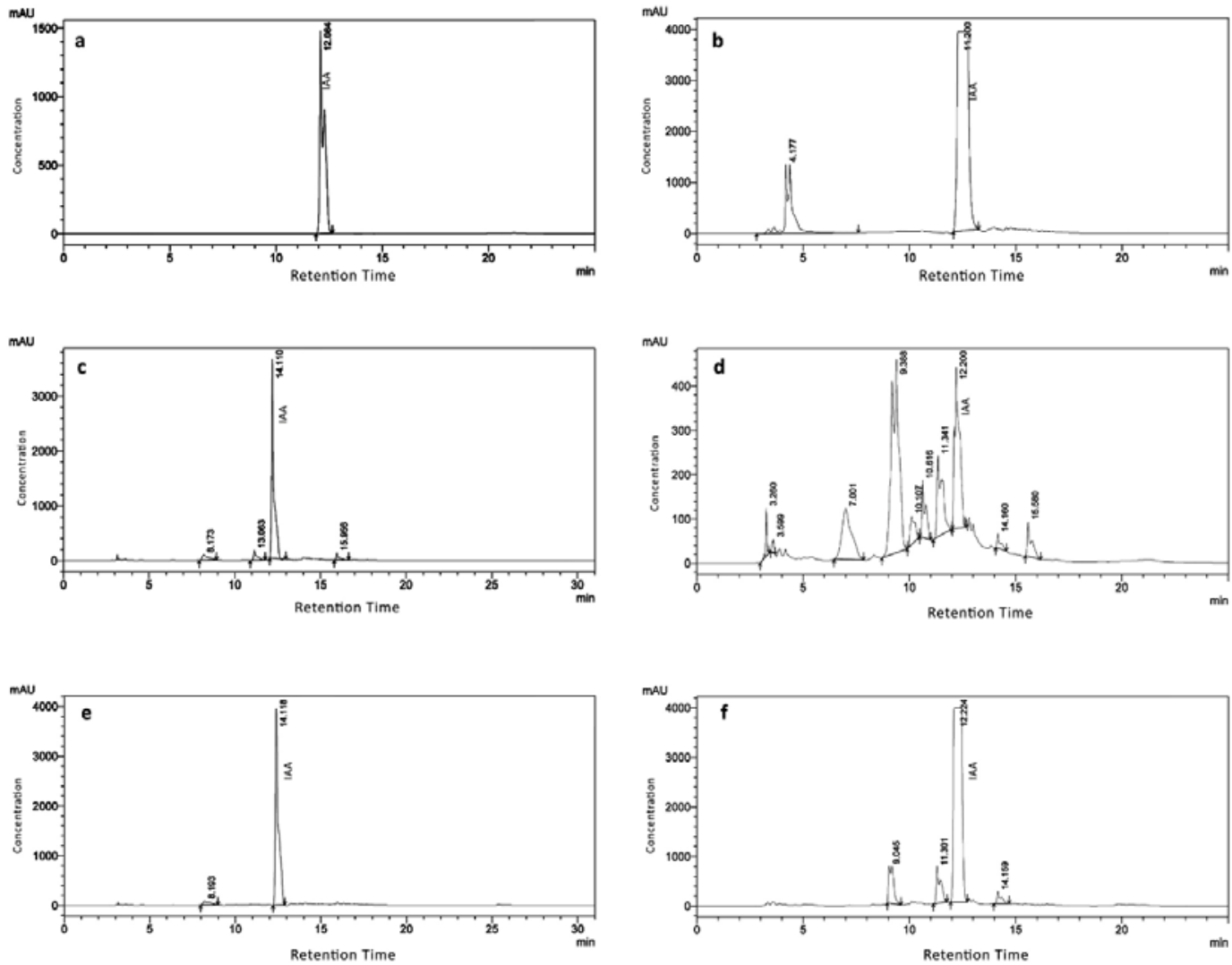

Figure 1. HPLC analysis of IAA in the culture supernatants of velamen root associated endophytic fungi growing in Potato dextrose broth. IAA form peaks in retention time $12 \mathrm{~min}$. (a) IAA Standard, (b) T. asperellum, (c) T. harzianum, (d) E. endophytica, (d). D. eucalyptorum, and (e) T. atroviride.

Table 1. Molecular identification of different OTUs with their accession number and in vitro synthesis of IAA.

\begin{tabular}{|c|c|c|c|c|c|}
\hline \multirow{3}{*}{$\begin{array}{c}\text { OTU } \\
\text { acronym }\end{array}$} & \multirow{3}{*}{ Taxon } & \multirow{3}{*}{$\begin{array}{c}\text { Gen Bank } \\
\text { Accession } \\
\text { number }\end{array}$} & \multicolumn{3}{|c|}{ Concentration of IAA } \\
\hline & & & \multirow{2}{*}{$\begin{array}{c}\text { Calorimetric } \\
\text { method } \\
\left(\mu \mathrm{g} \cdot \mathrm{mL}^{-1}\right)\end{array}$} & \multicolumn{2}{|c|}{ From HPLC method } \\
\hline & & & & $\begin{array}{c}\text { Area of } \\
\text { peak }\end{array}$ & $\begin{array}{c}\text { Concentration } \\
\mu \mathrm{g} \mathrm{mL} \mathrm{m}^{-1}\end{array}$ \\
\hline APVR 07 & Trichoderma asperellum & KY643785 & $544.97 \pm 4.32$ & 107685582 & 554 \\
\hline APVR 22 & Trichoderma harzianum & KY643781 & $167.86 \pm 4.23$ & 28351678 & 165 \\
\hline APVR 23 & $\begin{array}{c}\text { Endomelanconiopsis } \\
\text { endophytica }\end{array}$ & KY643782 & $191.23 \pm 2.30$ & 31980205 & 182 \\
\hline APVR 25 & Diaporthe eucalyptorum & KY643784 & $276.27 \pm 4.39$ & 48637185 & 266 \\
\hline APVR 33 & Trichoderma atroviridae & MF100153 & $289.87 \pm 2.55$ & 50989632 & 278 \\
\hline
\end{tabular}

APVR - Endophytic fungi isolated from velamen roots of Acampe praemorsa.

The phosphorus content of plantlets in all treatments showed statistically significant higher values than the control at $\mathrm{P}<0.001$ (Table 2). The phosphorus accumulation was the highest in the plantlets treated with T. atroviride $(0.44 \%)$ and lowest in the plantlets treated with T.asperellum $(0.13 \%)$. 
Table 2. Tissue N, P and K content in the leaf of Dendrobium sp. after 45 DAI.

\begin{tabular}{l|c|c|c}
\multicolumn{1}{c|}{ Treatments } & $\begin{array}{c}\text { Tissue nitrogen (\%) } \\
\text { F value 29.352 }\end{array}$ & $\begin{array}{c}\text { Tissue phosphorus (\%) } \\
\text { F value165.990 }\end{array}$ & $\begin{array}{c}\text { Tissue potassium (\%) } \\
\text { F value 674.074 }\end{array}$ \\
\hline Control & $1.42 \pm 0.19^{\mathrm{d}}$ & $0.09 \pm 0.01^{\mathrm{e}}$ & $0.63 \pm 0.01^{\mathrm{e}}$ \\
\hline T. asperellum & $2.02 \pm 0.23^{\mathrm{ab}}$ & $0.13 \pm 0.01^{\mathrm{d}}$ & $0.96 \pm 0.04^{\mathrm{c}}$ \\
\hline T. harzianum & $2.19 \pm 0.23^{\mathrm{a}}$ & $0.14 \pm 0.01^{\mathrm{d}}$ & $0.95 \pm 0.01^{\mathrm{c}}$ \\
\hline E. endophytica & $2.15 \pm 0.17^{\mathrm{a}}$ & $0.26 \pm 0.02^{\mathrm{c}}$ & $0.67 \pm 0.02^{\mathrm{d}}$ \\
\hline D. eucalyptorum & $1.97 \pm 0.11^{\mathrm{b}}$ & $0.32 \pm 0.03^{\mathrm{b}}$ & $1.26 \pm 0.04^{\mathrm{a}}$ \\
\hline T. atroviride & $1.64 \pm 0.11^{\mathrm{c}}$ & $0.44 \pm 0.03^{\mathrm{a}}$ & $1.00 \pm 0.02^{\mathrm{b}}$ \\
\hline
\end{tabular}

Values are mean \pm SD. Values with the different letter in the same column are significantly different after one way ANOVA and Duncan's Multiple Range Test (DMRT) at $P<0.001$ significance level.

The highest chlorophyll content in the leaves was noted in the plantlets treated with E. endophytica $(0.99 \mathrm{mg} / \mathrm{g})$, which was significantly higher $(P<0.05)$ than the control (Figure. 2) and the other treatments. The plantlets treated with D. eucalyptorum showed the lowest chlorophyll content in the leaves $(0.76$ $\mathrm{mg} / \mathrm{g}$ ).

The treatment with fungal inoculum, D. eucalyptorum showed the highest FW of leaves (9.99 g) after 45 DAI. The FW of the leaves was the lowest in plantlets treated with $T$. harzianum $(7.64 \mathrm{~g})$. The treatments with fungal inoculates T. harzianum, E. endophytica and D. eucalyptorum showed a statistically significant increase in the FW of leaves $(P<0.001)$ compared to the control (Figure 3). The plantlets treated with fungal inoculates T. asperellum, E. endophytica, D. eucalyptorum and T. atroviride showed a significant increase in DW of leaves in comparison with control at $P<0.001$ (Figure 4). The plantlets treated with $T$. atroviride showed a maximum increase in DW of leaves $(0.64 \mathrm{~g})$ and the treatments with
T. harzianum showed the minimum DW of leaves $(0.52 \mathrm{~g})$ after $45 \mathrm{DAI}$.

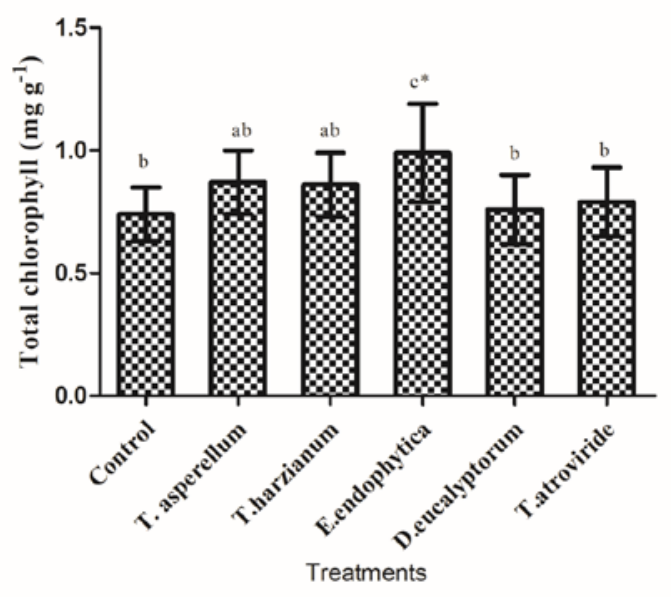

Figure 2. Chlorophyll content of the 3rd leaf of Dendrobium sp. after 45 DAI. Bar represents values in mean \pm SD. Bars of the same pattern with different letters are significantly different from control after one way ANOVA and Duncan's Multiple Range Test (DMRT) ${ }^{*} P<0.05$ and ${ }^{* *} P<0.001$. DAI Days of inoculation. 


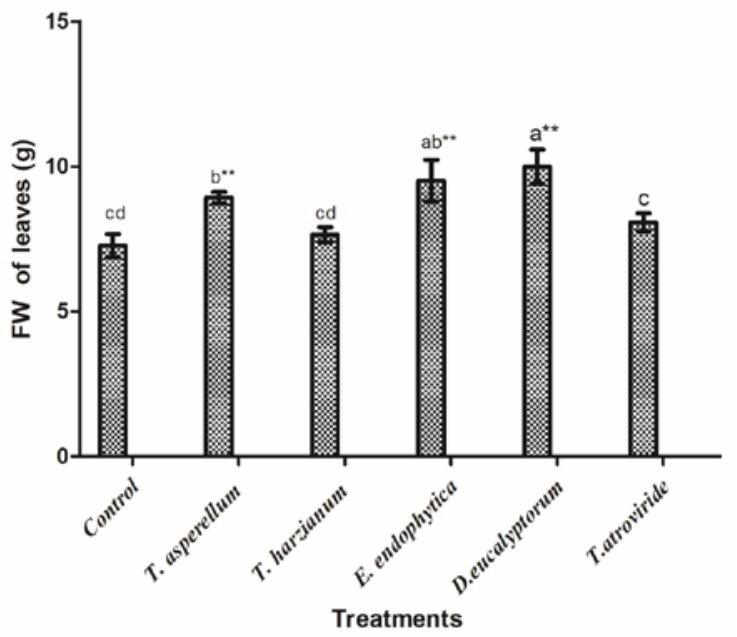

Figure 3. Fresh weight (FW ) of the leaves of Dendrobium sp. after 45 DAI. Bar represents values in mean \pm SD. Bars of the same pattern with different letters are significantly different from control after one way ANOVA and Duncan's Multiple Range Test (DMRT) ${ }^{* *} P<0.001$. DAI Days of inoculation.

\section{Discussion}

In the present study, five fungal isolates from the velamen roots of a wild Orchid $A$. praemorsa were found to be potent producers of IAA and all of them showed a positive influence on the vegetative growth and nutrient uptake in an ornamental Orchid Dendrobium sp. This observation conforms to the previous findings of Chen et al. (2010) who by pot experiments confirmed the similar growth-promoting influence after root inoculation of certain endophytic fungi in a medicinal orchid Dendrobium loddigesi. Similar to the present study, previously also endophytic fungi like Trichoderma spp., Phoma sp., Pencillium sp. and Paecilomyces formosus are shown to stimulate plant growth by producing plant growth hormone IAA in plants other than orchids. (Contreras-Cornejo et al., 2009; Khan et al., 2012; Waqas et al., 2012; Kedar et al., 2014). According to Novak et al. (2014) auxins play a significant role in Orchid development.

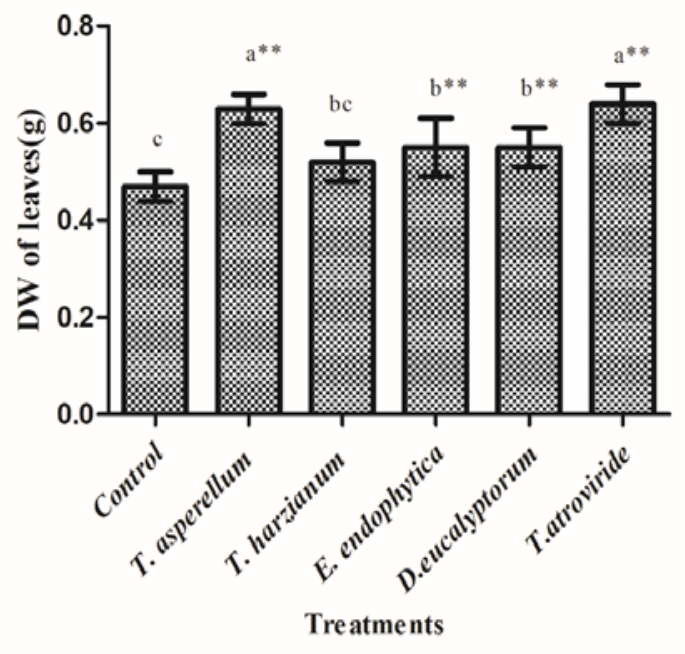

Figure 4. Dry biomass (DW) of the leaves of Dendrobium sp. after 45 DAI. Bar represents values in mean \pm SD. Bars of the same pattern with different letters are significantly different from control after one way ANOVA and Duncan's Multiple Range Test (DMRT) ** $P<0.001$. DAI - Days of inoculation.

Hou and Guo (2009) exposed the positive role of fungal endophytes in IAA production and their growth promotion in seedlings of Dendrobium sp. by cocultivation experiments. In addition, IAA produced by endophytic bacteria can stimulate growth in Orchid seedlings (Tsavkelova et al., 2007; Yang et al., 2014). Therefore, the positive influence of the five fungal isolates from the velamen roots of the wild Orchid on Dendrobium sp. can be attributed to the IAA production. However, growth promoting influence of endophytic fungi on their hosts cannot be always due to the IAA production and it may be due other growth promoting influences as well. Because phylogenetically different endophytes have different plant growth promoting abilities (Zhou et al., 2014) and nutrient uptake in Orchids (Zhao et al., 2014) through different mechanisms (El-Deeb et al,. 2012; Khan et al., 2012). Some produce plant growth promoting hormones like IAA and GA (Hamayun et al., 2009; Waqas et al., 2012; Shah et al., 
2019), some others degrade the growthretarding allelochemicals within the plants (Chen et al., 2011), or directly fix major nutrients like nitrogen (Muthukumrasamy et al., 2002) or increase the uptake of nutrients (Yedidia et al., 2001; Zhao et al., 2014). Although IAA production was used as the criteria for selecting a fungus for its growth promoting influence in the ornamental Orchid, the exact influence of the fungus in the growth promotion in the Dendrobium sp. was not identified in the present study. However, it is well known that endophytic fungi with the capability of in vitro production of IAA also have growth promotion ability in Orchids (Shah et al., 2019).

In general, Trichoderma spp. have been investigated for a long time as potential plant growth promoting agents in plants (Hasanloo et al., 2010; Sharma et al., 2012; Kamaruzzaman et al., 2016) other than Orchids. But the growth promoting effects of E. endophytica and $D$. eucalyptorum were observed for the first time. It is well known that Trichoderma spp. improve plant height, shoot weight, root length and root weight in wheat and soybean (Shivanna et al., 1996) as well as grain quality of wheat (Colla et al., 2015). Porras-Alfaro and Bayman, (2007) and Chen et al. (2010) have already suggested a positive effect of certain endophytic fungi on seed germination and plant growth in epiphytic orchids.

The present observation of the growth promoting influence of five endophytic isolates in the Dendrobium sp. is similar to that of Kedar et al. (2014) who observed an increase in FW and DW of Zea mays plantlets on treatment with endophytic fungi. The increase in FW and DW of Dendrobium sp. due to fungal inoculation may be partly attributed to the positive influence of them in increased uptake of nitrogen and phosphorus in the host plants (Zhao et al., 2014). In the present study, chlorophyll content of Dendrobium sp. inoculated with the fungal endophyte, $E$. endophytica was significantly increased in comparison with the control, which is a direct indication of the positive influence of the fungus on enhancing the vegetative growth of the plant. The higher content of chlorophyll in the treated plants than the control may be because of the increased uptake of nitrogen (Kim et al., 2010). In the present study treatments with all the fungal inoculants were found significantly enhancing the uptake and accumulation of major nutrients (NPK) in Dendrobium sp.

A direct fungal pathway for $\mathrm{N}$ flux to the Orchid has also been established (Cameron et al., 2006). Zhao et al. (2014) revealed that treatment with endophytic fungal inoculant shows a better uptake of nitrogen and phosphorus in Orchids. According to Yi et al. (2003), an increased amount of potassium in plants, in general, has a positive effect on hardening the plant tissue and controlling the disease. Overall, the present experimental investigation provided sufficient evidence for further intensive field experimental trial of velamen root-associated endophytic fungi as the means to alleviate environmental stress and growthpromotion in plants, especially ornamental Orchids. The findings have potential application in the promotion of organic cultivation of Orchids.

\section{Conclusion}

In the current study, it was found that five endophytic fungal isolates from the velamen root of a wild Orchid $A$. praemorsa are capable of producing phytohormone IAA. An experimental study of such five species of endophytic fungal isolates from the wild Orchid $A$. praemorsa was tried on Dendrobium sp. The study confirmed the positive growth-promoting roles of fungal endophytes from the velamen roots of wild orchids on growth characteristics such as increase in biomass and nutrientuptake in ornamental Orchids. However, 
the exact method of growth promotion in ornamentals by the endophytic fungi of velamen roots and the actual kinds of all the bioactive compounds that are involved in such growth enhancement require further investigation. The exact protocols of application of such fungal isolates from the velamen roots of wild Orchids on ornamental Orchids deserve further experimentation and standardization. Overall, the present findings provided sufficient empirical evidence that elicits the scope of application-trials of endophytic fungal formulations from wild Orchids in the Orchid floriculture.

\section{Acknowledgements}

The first author wishes to acknowledge the financial support extended to her by the University Grants Commission (UGC), Government of India, under its FDP programme (Order No: FIP/12th plan/KLMG016 TF 02, dated 6th January 2015) and the leave extended to her by the Management of the Catholicate College, Pathanamthitta, Kerala for carrying out this work. The research was funded by University Grants Commission (UGC), Government of India, under its FDP programme (Order No: FIP/12th plan/KLMG016 TF 02, dated 6th January 2015).

\section{Conflict of interests}

Authors declare that there are no conflicts of interest.

\section{References}

AOAC-Association of Official Agricultural Chemists. Official and tentative methods of analysis of the Association of Official Agricultural Chemists. Washington, DC: AOAC, 1978.

Arnon, D. I. Copper enzymes in iolated chloroplasts. Polyphenol oxidase in Beta vulgaris. Plant Physiology, v. 24, p. 1-15, 1949. https://doi.org/10.1104/pp.24.1.1
Bayman, P.; Lebrón, L. L.; Tremblay, R. L.; Lodge, D. J. Variation in endophytic fungi from roots and leaves of Lepanthes (Orchidaceae). New Phytologist, v. 135, p. 143-149, 1997.

Cameron, D. D.; Leake, J. R.; Read, D. J. Mutualistic mycorrhiza in orchids: Evidence from plant-fungus carbon and nitrogen transfers in the green-leaved terrestrial orchid Goodyera repens. New Phytologist, v. 171, p. 405-416, 2006.

Chen, L.; Yang, X., Raze; W., Li, J., Liu Y.; Qiu, M.; Zhang, F.; Shen, Q. Trichoderma harzianum SQR-T037 rapidly degrades allochemicals in rhizospheres of continuously cropped cucumbers. Applied Microbiology and Biotechnology, v. 89, no. 5, p. 1653-1663, 2011. https://doi.org/ 10.1007/s00253-010-2948-x

Chen, X. M.; Dong, H. L.; Hu, K. X.; Sun, Z. R.; Chen, J.; Guo, S. X. Diversity and antimicrobial and plant-growth-promoting activities of endophytic fungi in Dendrobium loddigesii Rolfe. Journal of Plant Growth Regulation, v. 29 , p. 328-337, 2010. https://doi.org/ 10.1007/s00344-010-9139-y

Colla, G.; Rouphael, Y.; Bonini, P.; Cardarelli, M. Coating seeds with endophytic fungi enhances growth, uptake, yield and grain quality of winter wheat. Interational Journal of Plant Production, v. 9, p. 171189, 2015.

Contreras-Cornej, H. A.; Macias-Rodriguez, L.; Cortes-Penagos, C.; Lopez-Bucio, J. Trichoderma virens, a plant beneficial fungus, enhances biomass production and promotes lateral root growth through an auxindependent mechanism in Arabidopsis. Plant Physiology, v. 149, p.1579-1592, 2009. https://doi.org/10.1104/pp.108.130369

Correll, D. S. Native orchids of North America. Massachusetts: Chronica Botanica Company, 1950.

Deepthi, A. S.; Ray, J. G. Endophytic diversity of hanging velamen roots in the epiphytic orchid Acampe praemorsa. Plant Ecology \& Diversity, v. 11, p.649-661, 2018. https://doi.org/10.1080/17550874.2019.16 10911

El-Deeb, B.; Bazaid, S.; Gherbawy, Y.; Elhariry, H. Characterization of endophytic bacteria associated with rose plant (Rosa damascena 
trigintipeta) during flowering stage and their plant growth promoting traits. Journal of Plant Interactions, v. 7, p. 248-253, 2012. https://doi.org/10.1080/17429145.2011.63 7161

Guo, B.; Wang, Y.; Sun, X.; Tang, K. Bioactive natural products from endophytes: A review. Applied Biochemistry and Microbiology, v. 44 , p. $136-142$, 2008. https://doi.org/ 10.1134/S0003683808020026

Hágsater, E.; Dumont, V. IUCN/SSC Orchid specialist group. Orchids-status survey and conservation action plan. UK: IUCN, 1996.

Hamayun, M.; Khan, S. A.; Khan, A. L.; Rahman, G.; Sohn, E.; Shan, A. A; Kim, S.; Joo, G.; Lee, I. Phoma herbarum as a new gibberellin-producing and plant growthpromoting fungus. Journal of Microbiology and Biotechnology, v. 19, p. 1244-1249, 2009.

Hamayun, M.; Khan, S. A.; Khan, A. L.; Rahman, G.; Kim, Y.; Iqbal, I.; Hussain, J.; Sohn, E.; Lee. I. Gibberellin production and plant growth promotion from pure cultures of Cladosporium sp. MH-6 isolated from cucumber (Cucumis sativus L.). Mycologia, v. 102, p. 989-995, 2010. https://doi.org/ 10.3852/09-261

Hasanloo, T.; Kowsari, M.; Naraghi, S. M.; Bagheri, O. Study of different Trichoderma strains on growth characteristics and silymarin accumulation of milk thistle plant. Journal of Plant Interactions, v. 5, p. 45-49, 2010. https://doi.org/10.1080/1742914090 3189166

Hermosa, R.; Viterbo, A.; Chet, I.; Monte, E. Plant-beneficial effects of Trichoderma and of its genes. Microbiology, v. 158, p. 17-25, 2012. https://doi.org/10.1099/mic.0. 052274-0

Hou, X. Q.; Guo, S. X. Interaction between a dark septate endophytic isolate from Dendrobium sp. and roots of D. nobile seedlings. Journal of Integrative Plant Biology, v. 51, p. 374-381, 2009. https://doi.org/10.1111/j.1744-7909.2008. 00777.x

Jackson, M. L. Soil chemical analysis. 2. ed. New Delhi: Prentice Hall of India, 1973.
Kamaruzzaman, M.; Rahman, M. M.; Islam, M. S.; Ahmad, M. U. Efficacy of four selective Trichoderma isolates as plant growth promoters in two peanut varieties. International Journal of Biological Research, v. 4, p. 152-156, 2016. https://doi.org/10.14419/ijbr.v4i2.6468

Kedar, A.; Rathod, D.; Yadav, A.; Agarkar, G.; Rai , M. Endophytic Phoma sp. isolated from medicinal plants promote the growth of Zea mays. Nusantara Bioscience, v. 6, p. 132$139,2014$.

Khan, A. L.; Hamayun, M.; Kang, S.-M.; Kang, S.-M.; Kim, Y.-H.; Jung, H.-Y.; Lee, J.-H; Lee, I.-J. Endophytic fungal association via gibberellins and indole acetic acid can improve plant growth under abiotic stress: an example of Paecilomyces formosus LHL10. BMC Microbiology, v. 12, Article 3, 2012. https://doi.org/10.1186/1471-2180-12-3

Khan, A. R.; Ullah, I.; Waqas, M.; Shahad, R.; Hong, S.; Park, G.; Jung, B. K.; Lee, I.; Shin, J. Plant growth-promoting potential of endophytic fungi isolated from Solanum nigrum leaves. World Journal of Microbiology and Biotechnology, v. 31, p. 1461-1466, 2015. https://doi.org/ 10.1007/s11274-015-1888-0

Khan, S. A.; Hamayun, M.; Khan, A. L.; Lee, I.; Shinwari, Z.; Kim, J. Isolation of plant growth promoting endophytic fungi from dicots inhabiting coastal sand dunes of Korea. Pakistan Jounal of Botany, v. 44, p. 14531460, 2012.

Kim, K.; Yim, W.; Trivedi. P. Synergistic effects of inoculating arbuscular mycorrhizal fungi and Methylobacterium oryzae strains on growth and nutrient uptake of red pepper (Capsicum annuum L.). Plant and Soil, v. 327, p. 429-440, 2010. https://doi.org/10.1007/ s11104-009-0072-4

Kohout, P.; Tesitelova, T.; Roy, M.; Vohnik, K.; Jersakova, J. A diverse fungal community associated with Pseudorchis albida (Orchidaceae) roots. Fungal Ecology, v. 6, p. 50-64, 2013. https://doi.org/10.1016/ j.funeco.2012.08.005

Mohamed, H.; Joseph, M. Isolation, identification and frequency studies of foliar endophytic fungi from Dendrobium sp. and 
Oncidium sp. International Journal of Recent Science Research, v. 7, p. 1458014583, 2016.

Muthukumrasamy, R.; Revathi, G.; Loganathan, P. Effect of inorganic $\mathrm{N}$ on the population, in vitro colonization and morphology of Acetobacter diazotrophicus (syn. Gluconacetobacter diazotrophicus). Plant and Soil, v. 243, p.91-102, 2002. https://doi.org/10.1023/A:1019963928947

Novak, S. D.; Luna, L. J.; Gamage, R. N. Role of auxin in orchid development. Plant Signaling Behavior, v. 9, e972277, 2014. https://doi.org/10.4161/psb.32169

Porras-Alfaro, A.; Bayman, P. Mycorrhizal fungi of Vanilla: Diversity, specificity and effects on seed germination and plant growth. Mycologia, v. 99, p. 510-525, 2007.

Schulz, B.; Wanke, U.; Draeger, S.; Aust, H. Endophytes from herbaceous plants and shrubs: Effectiveness of surface sterilization methods. Mycological Research, v. 97, p. 1447-1450, 1993. https://doi.org/ 10.1016/S0953-7562(09)80215-3

Senthilmurugan, G.; Sekar, S. Plant growth promoter and biocontrol mechanism of endophytic fungi Botrytis sp. Brazilian Journal of Biological Sciences, v. 2, no. 4, p. 221-233, 2015.

Shah, S.; Shrestha, R.; Maharjan, S.; Selosse, M.; Pant, B. Isolation and characterization of plant growth-promoting endophytic fungi from the roots of Dendrobium moniliforme. Plants, v. 8, p. 5-15, 2019. https://doi.org/ $10.3390 /$ plants8010005

Sharma, P.; Patel, A. N.; Saini, M. K.; Deep, S. Field demonstration of Trichoderma harzianum as a plant growth promoter in wheat (Triticum aestivum L). Journal of Agricultural Science, v. 4, p. 65-73, 2012. https://doi.org/10.5539/jas.v4n8p65

Shivanna, M. B.; Meera, M. S.; Kageyamma, K.; Hyakumachi, M. Growth promotion abiity of zoysiagrass rhizosphere fungi in consecutive plantings of wheat and soybean. Mycoscience, v. 37, p. 163-168, 1996. https://doi.org/10.1007/BF02461341

Tsavkelova, E. A.; Bömke, C.; Netrusov, A. I.; Weiner, J.; Tudzynski, B. Production of gibberellic acids by an orchid-associated Fusarium proliferatum strain. Fungal Genetics and Biology, v. 45, p. 1393-1403,
2008. https://doi.org/10.1016/j.fgb.2008. 07.011

Tsavkelova, E. A.; Cherdyntseva, T. A.; Klimova, S. Y.; Botina, S. G.; Netrusov, A. I. Orchid-associated bacteria produce indole-3acetic acid, promote seed germination, and increase their microbial yield in response to exogenous auxin. Archives of Microbiology, v. 188 , p. 655-664, 2007. https://doi.org/ 10.1007/s00203-007-0286-x

Tsavkelova, E. A.; Lobakova, E. S.; Kolomeitseva, G. L. Localization of associative Cyanobacteria on the roots of epiphytic orchids. Microbiology, v. 72, p.99-104, 2003. https://doi.org/10.1023/A:10222862 25013

Wang, Y.; Gao, B. L.; Li, X. X.; Zhang, Z. B.; Yan, R. M.; Yang, H. L.; Zhu, D. Phylogenetic diversity of culturable endophytic fungi in Dongxiang wild rice (Oryza rufipogon Griff), detection of polyketide synthase gene and their antagonistic activity analysis. Fungal Biology, v. 119, no. 11, p. 1032-1045, 2015. https://doi.org/10.1016/j.funbio.2015.07.009

Waqas, M.; Khan, A. L.; Kamran, M.; Hamayun, M.; Kang, S.; Kim,Y.; Lee, I. Endophytic fungi produce gibberellins and indoleacetic acid and promotes host-plant growth during stress. Molecules, v. 17, p. 10754-10773, 2012. https://doi.org/10.3390/molecules 170910754

Xing, Y.; Chen, J.; Cui, J.; Chen, S.; Guo, S. Antimicrobial activity and biodiversity of endophytic fungi in Dendrobium devonianum and Dendrobium thyrsiflorum from Vietman. Current Microbiology, v. 62, p. 1218-1224, 2011. https://doi.org/10.1007/s00284-0109848-2

Yang, S.; Zhang, X.; Cao, Z.; Zhao, K.; Wang, S.; Chen, M.; Hu, X. Growth-promoting Sphingomonas paucimobilis ZJSH1 associated with Dendrobium officinale through phytohormone production and nitrogen fixation. Microbial Biotechnology, v. 7, p.611-620, 2014. https://doi.org/10.1111/ 1751-7915.12148

Yedidia, I.; Srivastva, A. K.; Kapulnik, Y.; Chet, I. Effect of Trichoderma harzianum on microelement concentrations and increased growth of cucumber plants. Plant and Soil, v. 35 , p. 235-242, 2001. https://doi.org/ 10.1023/A:1011990013955 
Yi, Q.; Xin, F.; Ye, X. Effects of increasing phosphate and potassium fertilizers on the control of Cymbidium anthracnose. Journal of Tropical and Subtropical Botany, v. 11, p. 157-160, 2003.

Zhao, X. L.; Yang, J. Z.; Liu, S.; Chen, C.; Zhu, H.; Cao, J. The colonization patterns of different fungi on roots of Cymbidium hybridum plantlets and their respective inoculation effects on growth and nutrient uptake of orchid plantlets. World Journal of Microbiology and Biotechnology, v. 30, p. 1993-2003, $2014 . \quad$ https://doi.org/ 10.1007/s11274-014-1623-2

Zhou, Z.; Zhang, C.; Zhou, W.; Li, W.; Chu, L.; Yan, J.; Li, H. Diversity and plant growthpromoting ability of endophytic fungi from the five flower plant species collected from Yunnan, Southwest China. Journal of Plant Interaction, v. 9, p.585-591, 2014. https://doi.org/10.1080/17429145.2013.87 3959

Zotz, G.; Hietz, P. The physiological ecology of vascular epiphytes: Current knowledge, open questions. Journal of Experimental Botany, v. 52, p. 2067-2078, 2001. https://doi.org/ $10.1093 /$ jexbot/52.364.2067

Zotz, G.; Winkler, U. Aerial roots of epiphytic orchids: The velamen radicum and its role in water and nutrient uptake. Oecologia, v. 171, p. 733-741, 2013. https://doi.org/10.1007/ s00442-012-2575-6

License information: This is an open-access article distributed under the terms of the Creative Commons Attribution License, which permits unrestricted use, distribution, and reproduction in any medium, provided the original work is properly cited. 